\title{
Effect of Land Configuration and Nutrient Management in Kharif Maize on Phosphorous Uptake
}

\author{
A.C. Yadav", Karam Husain*, U.S. Tiwari, V.K. Verma, \\ M.Z. Siddiqui and Naushad Khan \\ Department of Agronomy, Chandra Shekhar Azad University of Agriculture and Technology, \\ Kanpur-208002, India \\ *Corresponding author
}

\section{A B S T R A C T}

\begin{tabular}{|l|}
\hline Ke y w or d s \\
Content in grain, \\
Land configuration, \\
LCC, NPK uptake \\
\hline Article Info \\
\hline Accepted: \\
12 June 2019 \\
Available Online: \\
10 July 2019 \\
\hline \hline
\end{tabular}

A field experiment was conducted during two consecutive Kharif (2016 and 2017) at Students' Instructional Farm, Department of Agronomy, C. S. Azad University of Agriculture and Technology, Kanpur. The present study consisted of five land configurations as main plot treatments viz., broadcasting, flat sowing, flat followed by earthing, narrow bed and furrow and broad bed and furrow and four nutrient management practices as sub plot treatments viz., basal dose of NPK + top dressing of N in two splits, basal dose of NPK + foliar spray of N in two splits, basal dose of NPK + N through LCC and basal doses of $\mathrm{P}$ and $\mathrm{K}+\mathrm{N}$ through LCC only, and was laid out in split plot design and replicated thrice. The soil of experimental site was sandy loam in texture, low in organic carbon and available nitrogen, medium in available phosphorous and potassium. The hybrid variety (DKC9144) was sown as per treatment in plant geometry $(50 \times 25 \mathrm{~cm})$ maintained by thinning. The present investigation revealed that the seed sown in broad bed and furrow accumulated significantly highest nitrogen (grain $1.42 \%$ and stover $0.60 \%$ ), phosphorus (grain $0.33 \%$ and stover $0.17 \%$ ) and potassium (grain $0.38 \%$ and stover $1.10 \%$ ) contents and uptake of these nutrients was also maximum in the same treatment i.e., nitrogen (grain 98.3 and stover $76.5 \mathrm{~kg} \mathrm{~h}^{-1}$ ), phosphorus (grain 42.0 and stover 21.4 $\mathrm{kg} \mathrm{ha}^{-1}$ ) and potassium (grain 26.5 and stover $140.8 \mathrm{~kg} \mathrm{ha}^{-1}$ ) in pooled analysis. Hybrid maize accumulation significantly higher through basal dose of NPK $+\mathrm{N}$ through LCC nutrient content when fertilizer nitrogen (grain $1.42 \%$ and stover $0.60 \%$ ), phosphorus (grain $0.33 \%$ and stover $0.17 \%$ ) and potassium (grain $0.38 \%$ and stover $1.10 \%$ ) there by uptake in grain and stover was also higher nitrogen (grain 95.9 and stover $75.3 \mathrm{~kg} \mathrm{ha}^{-1}$ ), phosphorus (grain 41.3 and stover $21.1 \mathrm{~kg} \mathrm{~h}^{-1}$ ) and potassium (grain 25.8 and stover 138.4 $\mathrm{kg} \mathrm{ha}^{-1}$ ) in pooled analysis. Maximum improvement in available status of nitrogen (305.0 $\left.\mathrm{kg} \mathrm{ha}^{-1}\right)$, phosphorous $\left(18.9 \mathrm{~kg} \mathrm{ha}^{-1}\right)$ and potassium $\left(244.0 \mathrm{~kg} \mathrm{ha}^{-1}\right)$ was recorded with broad bed and furrow method followed by narrow bed and furrow system and minimum at broad casting systems over its initial values. In nutrient management system highest increase in available status of $\mathrm{N}, \mathrm{P}$ and $\mathrm{K}$ was recorded in basal dose of NPK $+\mathrm{N}$ through LCC followed by basal dose of $\mathrm{P}$ and $\mathrm{K}+\mathrm{N}$ through LCC only over its initial values. 


\section{Introduction}

Maize (Zea mays L.), is the third most important crop in India after rice and wheat. Globally, India stands at $5^{\text {th }}$ rank in acreage while in production it is at $8^{\text {th }}$ rank. It is cultivated on 9.26 million hectares area with a production of 21.81 million tonnes having productivity of $25.10 \mathrm{q} \mathrm{ha}^{-1}$ and contributes about 3\% towards total world production (Anonymous, 2016). Maize is an important and versatile cereal being grown over diverse uses i.e. human food, poultry feed and fodder for livestock as well as raw material for industries. India earns ₹ 100 billion and provides employment of nearly 100 million man days as this crop has become as commercial crop rather than food crop. At present, this crop is being grown for poultry feed $(52 \%)$, human food (24\%), animal feed $(11 \%)$, starch (11\%), brewery (1\%) and seed (1\%) (Sain Dass et al., 2007). India may have to produce 55 million tonnes of maize to cope up with human consumption as well as poultry, piggery, pharma industry and fodder needs by 2030 (Anonymous, 2013). Alcoholic beverages, food sweeteners, starch, oil and proteins may also be produced with maize crop.

Land configuration plays a major role in minimizing soil erosion and improving water and nutrient use efficiency of field crops (Chiroma et al., 2008) achieved. Easy and uniform germination along with growth and development of plant are achieved by manipulation of sowing methods and also increased availability of nutrients. The superiority of ridges and furrow system could be ascribed to proper drainage of excess water coupled with adequate aeration at the time of irrigation or heavy rainfall. Ridges and furrow method of sowing has been found to improve grain as well as stover yield of maize over the flat bed method of sowing (Parihar et al., 2009).
Nitrogen (N) management is one of the most important factor required for improving crop productivity and profitability under semiarid climates (Amanullah, 2016). $\mathrm{N}$ is the most yield-restraining nutrient in crop production at global level (Guo et al., 2016).

Managing nitrogen to match crop requirement is an important tip for maize cultivation. Six panel LCC developed jointly by International Rice Research Institute and Philippines Rice Research Institute could play key role for the management of nitrogen in maize crop. The LCC is easy-to-use and low cost diagnostic tool for monitoring the relative greenness of a plant leaf, an indicator of the plant nitrogen status. The nitrogen status of plant is manifested on the greenness of its leaves. The crop's demand for nitrogen varies on its growing period thus assessment and monitoring of the required nitrogen content must be done periodically. LCC is basically a guide to supply the necessary nitrogen fertilizer for the optimal nitrogen content which is very necessary in achieving maximum yield. Matching fertilizer nitrogen supply with crop demand using threshold LCC shade 5 saved $25-50 \%$ fertilizer nitrogen (Clements, 1964).

\section{Materials and Methods}

Field experiment was conducted for two consecutive Kharif, 2016 and 2017 at Students' Instructional Farm (SIF), C.S. Azad University of Agriculture and Technology, Kanpur, Uttar Pradesh, India. Factors included in the study were land configurations in main plot viz. Broadcasting, Flat sowing, Flat followed by earthing, Narrow bed \& furrow and Broad bed \& furrow and nutrient management in sub plot viz. Basal dose of $\mathrm{NPK}+$ top dressing of $\mathrm{N}$ in two splits, Basal dose of NPK + Foliar spray of N in two splits, Basal dose of NPK $+\mathrm{N}$ through LCC and basal dose of $\mathrm{P} \& \mathrm{~K}+\mathrm{N}$ through LCC only. 
Entire dose of recommended phosphorus, potassium, and half dose of nitrogen were applied as basal and remaining half of the nitrogen was either as top dressing in two equal splits or sprayed twice at 30 DAS and at tasseling stage as per treatment. The nitrogen was also applied with the help of Leaf Colour Chart (LCC) readings fell below the 5-4.5 critical value of leaf colour. The soil of experimental field was sandy loam in texture with $(53.90 \& 54.00 \%)$ sand, $(27.1 \& 27.2 \%)$ silt, (19.00 \& $18.80 \%)$ clay and a $\mathrm{pH}$ of $(7.80$ $\&$ 7.85) being 2016 and 2017, respectively. It was moderately fertile being low in organic carbon $(0.34 \& 0.37 \%)$ and available $\mathrm{N}$ $\left(170.40 \& 175.50 \mathrm{~kg} \mathrm{ha}{ }^{-1}\right)$, medium in available $\mathrm{P}_{2} \mathrm{O}_{5}\left(14.10 \& 14.20 \mathrm{~kg} \mathrm{ha}^{-1}\right)$ and $\mathrm{K}_{2} \mathrm{O}$ (154.0 \& $\left.156.25 \mathrm{~kg} \mathrm{ha}^{-1}\right)$ during 2016 and 2017, respectively. The experimental design was split plot with three replications.

Crop responses to the treatments were measured in terms of predetermined quantitative characters. The year wise observation recorded was subjected to statistical analysis (Fisher and Yates, 1975). Valid comparisons between various treatments were drawn using the respective $\mathrm{CD}$ (Critical difference) values. The soil samples $(0-15 \mathrm{~cm})$ from each treatments were collected, initial and after harvest of the crop during each years and analyzed for $\mathrm{pH}$, EC, DC, available nitrogen, phosphorous and potassium by standard method. The total nitrogen content in the plant samples of stover and cob at harvest was estimated by following modified microKjeldahl method (Jackson, 1973). Total phosphorus and potassium of plant samples at harvest were extracted by wet oxidation method using triacid mixture (conc. $\mathrm{HNO}_{3}: \mathrm{H}_{2} \mathrm{SO}_{4}: \mathrm{HClO}_{4}$ in 10:1:4 ratio). Phosphorus content was estimated by vanadomolybdate yellow colour method (Jackson, 1973), and potassium content was determined by flame photometer method (Jackson, 1973).
Uptake of $\mathbf{N}, \mathbf{P}$ and $\mathrm{K}$ by grain

Nutrient uptake $\left(\mathrm{kg} \mathrm{ha}^{-1}\right)=\frac{\% \text { ofNPK concentration in grain } X \text { grain yield }\left(\mathrm{kg} \mathrm{ha}^{-1}\right)}{100}$

Uptake of N, P and K by Stover

Nutrient uptake $\left(\mathrm{kg} \mathrm{ha}^{-1}\right)=\frac{\% \text { of NPK concentuation in stover X Stoveryield }\left(\mathrm{kg} \mathrm{ha}^{-1}\right)}{100}$

\section{Total uptake}

Total uptake of N, P and $\mathrm{K}$ was calculated for each treatment separately by using the following formula.

Total nitrogen uptake $\left(\mathrm{kg} \mathrm{ha}^{-1}\right)=\mathrm{N}$ uptake by grain $+\mathrm{N}$ uptake by stover

Uptake of $\mathrm{N}, \mathrm{P}$ and $\mathrm{K}$ by maize plants was expressed in $\mathrm{kg} \mathrm{ha}^{-1}$.

\section{Results and Discussion}

\section{Effect of treatment on nitrogen, phosphorous and potassium content}

The data depicted in Table 1 revealed the significant superiority of broad bed and furrow method of sowing in respect of nitrogen content in grain $(1.42 \%)$ over broadcasting and flat sowings. The nitrogen content in the stover $(0.60 \%)$ was also significantly higher in the same treatment but it was significantly superior to all. Phosphorous content $(0.33 \%)$ in grain and stover $(0.17 \%)$ as well as potassium content in grain $(0.38 \%)$ and stover $(1.10 \%)$ were also recorded significantly higher when sowing was performed in broad bed and furrow. However, narrow bed and furrow method sowing was found to be at par in respect of phosphorous content in stover and potassium content in grain and stover both. Among nutrient management methods, application of NPK in basal $+\mathrm{N}$ through LCC excelled all the treatment significantly in 
respect of nitrogen content in grain $(1.42 \%)$ and stover $(0.60 \%)$ except for nitrogen content in grain recorded with basal application of $\mathrm{NPK}+$ top dressing of remaining $\mathrm{N}$ in two splits being at par. Phosphorous content in grain $(0.33 \%)$ and stover $(0.17 \%)$ was also recorded significantly higher than all the treatments under test. Whereas potassium content in grain was recorded equal in all the first three treatments $(0.38 \%)$ and test was significantly superior then basal application $\mathrm{P}$ $\& \mathrm{~K}+\mathrm{N}$ through LCC only.

Potassium content in stover $(1.10 \%)$ was estimated significantly higher in basal application of NPK $+\mathrm{N}$ through LCC over all the remaining treatments under test. It is also clear from Table 1 that the content of $\mathrm{P}$ and $\mathrm{K}$ in grain was found to be higher than $\mathrm{N}$ content and $\mathrm{P}$ content in stover but content of the $\mathrm{K}$ was recorded higher in stover as compared to grain. Meena et al., (2007) were also of the similar opinion

The present studies indicated that the seeds sown in broad bed and furrow accumulated significantly highest nitrogen, phosphorus and potassium content in grains and stover than the seeds sown through broad casting in pooled analysis.

Among the nutrient management the application of nutrients through basal dose of $\mathrm{NPK}+\mathrm{N}$ through LCC accumulated significantly highest nitrogen, phosphorus and potassium in grain as well as in stover as compared to nutrient application by basal dose of $\mathrm{NPK}+\mathrm{N}$ through LCC in pooled analysis.

This might be due to the nutrients from initial stage to the maturity of the plants. The nutrient availability provide good nourishment of the plants and vigorous growth and synthesis of these nutrients in the plant cells which leads concentration of nutrients in the grain as well as stover.
Effect of the treatment on nitrogen, phosphorous and potassium uptake

Sowing of maize in broad bed and furrow recorded significantly maximum uptake of nitrogen in grain $\left(98.3 \mathrm{~kg} \mathrm{ha}^{-1}\right)$ and stover (76.5 $\mathrm{kg} \mathrm{ha}^{-1}$ ) as compared to all the remaining methods of sowing except for narrow bed and furrow being at par. The uptake phosphorous and potassium also recorded significantly higher in same treatment and narrow bed and furrow was at par in this regards too. The uptake of phosphorous in grain $\left(42 \mathrm{~kg} \mathrm{ha}^{-1}\right)$ and stover $\left(21.4 \mathrm{~kg} \mathrm{ha}^{-1}\right)$ as well as potassium in grain $\left(26.5 \mathrm{~kg} \mathrm{ha}^{-1}\right)$ and stover $(140.8 \mathrm{~kg}$ $\mathrm{ha}^{-1}$ ) excavated the significant superiority of broad bed and furrow sowing.

Among nutrient management practices, basal application of NPK $+\mathrm{N}$ through LCC superseded to all the remaining method of fertilizer application with significant margin except for $\mathrm{N}$ and $\mathrm{K}$ uptake in grain due to basal application NPK + top dressing of remaining $\mathrm{N}$ in two splits being at par. It is also clear from the Table 2 that nitrogen and phosphorous uptake by grain was recorded higher as compared to stover while potassium uptake by stover recorded higher as compare to grain because of content of the respective nutrient where also in the same manner. Gaurav et al., (2017) also recorded similar result.

Improved yield and yield attributes might be interpreted as the manifestation of highest nutrient uptake by the plants. The seeds sown in broad bed and furrow recorded significantly highest nitrogen, phosphorus and potassium uptake by grain and stover than seeds sown through broad casting, flat sowing and flat followed by earthing in pooled analysis. The results is corroborated with the findings of Owla et al., (2015) who have reported that the seeds sown in raised bed, uptake maximum NPK. 
Table.1 Pooled effect of treatments on nitrogen, phosphorous and potassium content (\%) in grain and stover of Hybrid Maize

\begin{tabular}{|c|c|c|c|c|c|c|c|}
\hline \multicolumn{2}{|r|}{ Treatments } & \multicolumn{2}{|c|}{$\mathrm{N}$ content $\%$} & \multicolumn{2}{|c|}{$P$ content $\%$} & \multicolumn{2}{|c|}{$K$ content $\%$} \\
\hline A. & Sowing Methods & Grain & Stover & Grain & Stover & Grain & Stover \\
\hline 1. & Broad casting & 1.37 & 0.58 & 0.32 & 0.16 & 0.37 & 1.06 \\
\hline 2. & Flat sowing & 1.38 & 0.58 & 0.32 & 0.16 & 0.37 & 1.07 \\
\hline 3. & Flat followed by earthing & 1.40 & 0.59 & 0.32 & 0.16 & 0.38 & 1.08 \\
\hline 4. & Narrow bed \& furrow & 1.41 & 0.59 & 0.32 & 0.17 & 0.38 & 1.09 \\
\hline 5. & Broad bed \& furrow & 1.42 & 0.60 & 0.33 & 0.17 & 0.38 & 1.10 \\
\hline 6. & SEm \pm & 0.01 & 0.002 & 0.001 & 0.001 & 0.001 & 0.003 \\
\hline 7. & $\mathrm{CD}(\mathrm{P}=0.05)$ & 0.02 & 0.005 & 0.002 & 0.001 & 0.003 & 0.010 \\
\hline B. & Nutrient management & & & & & & \\
\hline 1. & $\begin{array}{l}\text { Basal dose of NPK + top dressing of } \\
\mathrm{N} \text { in two splits }\end{array}$ & 1.40 & 0.59 & 0.32 & 0.16 & 0.38 & 1.08 \\
\hline 2. & $\begin{array}{l}\text { Basal dose of NPK }+ \text { Foliar spray of } \\
\mathrm{N} \text { in two split }\end{array}$ & 1.39 & 0.58 & 0.32 & 0.16 & 0.38 & 1.07 \\
\hline 3. & Basal dose of NPK $+\mathrm{N}$ through LCC & 1.42 & 0.60 & 0.33 & 0.17 & 0.38 & 1.10 \\
\hline 4. & $\begin{array}{l}\text { Basal dose of P \& } \mathrm{K}+\mathrm{N} \text { through } \\
\text { LCC only }\end{array}$ & 1.38 & 0.58 & 0.32 & 0.16 & 0.37 & 1.06 \\
\hline 5. & SEm \pm & 0.01 & 0.003 & 0.001 & 0.001 & 0.001 & 0.004 \\
\hline 6. & $\mathrm{CD}(\mathrm{P}=0.05)$ & 0.02 & 0.009 & 0.003 & 0.003 & 0.004 & 0.014 \\
\hline
\end{tabular}


Table.2 Pooled effect of treatments on nitrogen, phosphorous and potassium uptake $\left(\mathrm{kg} \mathrm{ha}^{-1}\right)$ by grain and stover of Hybrid Maize

\begin{tabular}{|c|c|c|c|c|c|c|c|}
\hline \multicolumn{2}{|r|}{ Treatments } & \multicolumn{2}{|l|}{$\mathbf{N}$} & \multicolumn{2}{|l|}{$\mathbf{P}$} & \multicolumn{2}{|l|}{$\mathbf{K}$} \\
\hline A. & Sowing Methods & Grain & Stover & Grain & Stover & Grain & Stover \\
\hline 1. & Broad casting & 75.5 & 59.4 & 32.6 & 16.4 & 20.4 & 109.0 \\
\hline 2. & Flat sowing & 83.8 & 65.1 & 35.7 & 18.2 & 22.5 & 119.6 \\
\hline 3. & Flat followed by earthing & 89.2 & 69.4 & 38.2 & 19.4 & 24.2 & 127.9 \\
\hline 4. & Narrow bed \& furrow & 94.4 & 73.5 & 40.2 & 20.6 & 25.3 & 134.5 \\
\hline 5. & Broad bed \& furrow & 98.3 & 76.5 & 42.0 & 21.4 & 26.5 & 140.8 \\
\hline 6. & SEm \pm & 1.3 & 1.2 & 1.0 & 0.4 & 0.4 & 2.2 \\
\hline 7. & $\mathrm{CD}(\mathrm{P}=0.05)$ & 3.9 & 3.7 & 2.0 & 1.1 & 1.1 & 6.7 \\
\hline B. & Nutrient management & & & & & & \\
\hline 1. & $\begin{array}{l}\text { Basal dose of NPK + top dressing of } \\
\mathrm{N} \text { in two splits }\end{array}$ & 92.8 & 70.8 & 38.8 & 19.8 & 25.0 & 130.1 \\
\hline 2. & $\begin{array}{l}\text { Basal dose of NPK + Foliar spray of } \\
\mathrm{N} \text { in two split }\end{array}$ & 85.1 & 66.3 & 36.3 & 18.5 & 22.9 & 121.5 \\
\hline 3. & Basal dose of NPK $+\mathrm{N}$ through LCC & 95.9 & 75.3 & 41.3 & 21.1 & 25.8 & 138.4 \\
\hline 4. & $\begin{array}{l}\text { Basal dose of } \mathrm{P} \& \mathrm{~K}+\mathrm{N} \text { through } \\
\text { LCC only }\end{array}$ & 79.1 & 62.8 & 34.5 & 17.6 & 21.4 & 115.6 \\
\hline 5. & SEm \pm & 1.2 & 1.0 & 0.5 & 0.3 & 0.3 & 1.9 \\
\hline 6. & $\mathrm{CD}(\mathrm{P}=0.05)$ & 3.3 & 2.9 & 1.5 & 0.8 & 1.0 & 5.4 \\
\hline
\end{tabular}


Table.3 Pooled effect of treatments on available Nitrogen, Phosphorous and Potassium in soil at harvest $\left(\mathrm{kg} \mathrm{ha}^{-1}\right)$ of Hybrid Maize

\begin{tabular}{|c|c|c|c|c|}
\hline \multicolumn{2}{|r|}{ Treatments } & \multirow[t]{2}{*}{ Available N (kg ha $\left.{ }^{-1}\right)$} & \multirow[t]{2}{*}{ Available $\mathbf{P}\left(\mathrm{kg} \mathrm{ha}^{-1}\right)$} & \multirow{2}{*}{ Available K (kg ha } \\
\hline A. & Sowing Methods & & & \\
\hline 1. & Broad casting & 293.5 & 18.3 & 235.0 \\
\hline 2. & Flat sowing & 296.5 & 18.4 & 237.1 \\
\hline 3. & Flat followed by earthing & 300.3 & 18.6 & 240.1 \\
\hline 4. & Narrow bed \& furrow & 302.3 & 18.8 & 241.7 \\
\hline 5. & Broad bed \& furrow & 305.0 & 18.9 & 244.0 \\
\hline 6. & SEm \pm & 4.8 & 0.3 & 3.8 \\
\hline 7. & $\mathrm{CD}(\mathrm{P}=0.05)$ & NS & NS & NS \\
\hline $\mathbf{B}$ & Nutrient management & & & \\
\hline 1. & $\begin{array}{l}\text { Basal dose of NPK + top dressing of } \mathrm{N} \\
\text { in two splits }\end{array}$ & 300.1 & 18.6 & 240.2 \\
\hline 2. & $\begin{array}{l}\text { Basal dose of NPK + Foliar spray of } \mathrm{N} \\
\text { in two split }\end{array}$ & 297.8 & 18.5 & 238.2 \\
\hline 3. & Basal dose of NPK $+\mathrm{N}$ through LCC & 304.7 & 18.9 & 243.5 \\
\hline 4. & $\begin{array}{l}\text { Basal dose of } \mathrm{P} \& \mathrm{~K}+\mathrm{N} \text { through } \mathrm{LCC} \\
\text { only }\end{array}$ & 295.6 & 18.3 & 236.4 \\
\hline 5. & SEm \pm & 4.0 & 0.2 & 3.2 \\
\hline 6. & $\mathrm{CD}(\mathrm{P}=0.05)$ & NS & NS & NS \\
\hline
\end{tabular}


Application of nutrient through basal dose of $\mathrm{NPK}+\mathrm{N}$ through LCC recorded significantly the highest nitrogen, phosphorus and potassium uptake by grain, stover and total uptake than the nutrient application through Basal dose of NPK + Foliar spray of N in two split and Basal dose of $\mathrm{P} \& \mathrm{~K}+\mathrm{N}$ through LCC only in pooled analysis. This might be due to nutrient availability during the whole crop cycle. The application of nitrogen with the help of leaf colour chart has provided required nitrogen for the chlorophyll development (Table 3).

\section{Effect of treatment on availability of major nutrients after harvest of the crop}

Fertility status of soil in all the treatments increased over its initial values. Maximum increases in available status of nitrogen, phosphorous and potassium in sowing method was observed with broad bed and furrow system and minimum at broad casting system in pooled analysis. Nutrient management system also showed slight improvement in fertility status of soil in all the treatments over its initial values. Highest status of available nitrogen (304.7 $\mathrm{kg} \mathrm{ha}^{-1}$ ), phosphorous (18.9 $\mathrm{kg} \mathrm{ha}^{-1}$ ) and potassium (243.5 kg ha ${ }^{-1}$ ) was recorded with basal $+\mathrm{N}$ through $\mathrm{LCC}$ in pooled analysis followed by basal dose of $\mathrm{P} \&$ $\mathrm{K}+\mathrm{N}$ through LCC only and minimum at basal dose of NPK + top dressing of $\mathrm{N}$ in two splits.

The seeds sown in broad bed and furrow and nutrient applied through basal dose of NPK + $\mathrm{N}$ through LCC recorded maximum $\mathrm{N}, \mathrm{P}$ and $\mathrm{K}$ content and uptake in grain and stover in pooled data basis. The available $\mathrm{N}, \mathrm{P}$ and $\mathrm{K}$ $\mathrm{kg} \mathrm{ha}^{-1}$ in soil accumulated maximum when seeds sown in broad bed and furrow with nutrient application as basal dose of NPK $+\mathrm{N}$ through LCC in pooled analysis. Thus it would be beneficial to row the maize in broad bed and furrow and apply fertilizer @ basal application of NPK $+\mathrm{N}$ through LCC to sustain the availability of nutrient to hybrid maize production during kharif season.

\section{References}

Amanullah, Yasir M., Khan A. Z., Tariq Jan M. (2016). Phenology, growth, and grain yield of maize as influenced by foliar applied urea at different growth stages. J. Plant Nutr. 33, 71-79.

Anonymous (2016). Annual report Directorate of Economics \& Statistics, Department of Agriculture, Cooperation and Farmers welfare Fourth Advance Estimates of Production of Food grains, pp.171.

Anonymous (2013). Agricultural Statistics at a Glance, Directorate of economics and statistics, Department of Agriculture and Cooperation, pp. 86

Chiroma, A. M., Alhassan, A. B. and Khan, B. (2008). Yield and water use efficiency of millet as affected by land configuration treatments. J. Sustainable Agric. 32 (2): 321 - 333.

Clements, H.F., (1964), Interaction of factors affecting yield, Ann. Rev. Pl. Physiol., 15: 409-422.

Fisher, E.D. and Yates, F. (1975). Statistical table for biological, Agriculture and Medical Research. Oliver and Boys, London: sixth edition; pp 110-119 and 174-176.

Gaurav, Verma, S.K., Meena, R.S., Maurya, A.C. and Kumar S. (2017). Nutrients Uptake and Available Nutrients Status in Soil as Influenced by Sowing Methods and Herbicides in Kharif Maize (Zea mays L.). International Journal of Agriculture, Environment and Biotechnology. 11(1): 17-24

Guo C., Li P., Lu J., Ren T., Cong R. and Li $X$. (2016). Application of controlled release urea in rice reducing environmental risk while increasing 
grain yield and improving nitrogen use efficiency. Commun. Soil Sci. Plant Anal. 47, 1176-1183.

Jackson, M.L. (1973). Soil chemical analysis, prentice Hall of India, Pvt. Ltd, New Delhi.

Lindsay, W.I. and Norvel, W.A. (1978). Development of DTPA test for Zn, Fe, Mn, and Co. Soil Sci. Soc. Amer. J. 15 (2): 421-428.

Meena, O., Khafi, H.R., Shekh, M.A. Mehta, A.C. and Davda, B.K. (2007). Effect of vermicompost and NPK on content, uptake and yield of rabi maize (Zea mays L.). Crop Research, 33(1): 53-54.

Owla, M.L., Nepalia, V., Chouhan, G.S. and Singh, Dilip (2015). Effect of fertility levels, nutrient sources and weed control on weed dynamic and yield of quality protein maize and relative nitrogen and phosphorus uptake. Indian Journal of Agronomy. 60(2): 267.

Parihar, C.M., Rana, K.S and Kantwa, S.R. (2009). Nutrient management in pearlmillet (Pennisetun glaucum) mustard (Brassica juncea) cropping system as affected by land configuration under limited irrigation. Indian Journal of Agronomy. 55(3): 191-196.

Sain Dass.; Singh, K.P. and Yadav, V.K. (2007). Present status and potential of maize hybrids in enhancing the productivity. National Conference on "Doubling Maize Production" organized by IFFCO Foundation, ICAR, DMR, DAC \& IFFCL at New Delhi, pp. 13-19.

\section{How to cite this article:}

Yadav, A.C., Karam Husain, U.S. Tiwari, V.K. Verma, M.Z. Siddiqui and Naushad Khan. 2019. Effect of Land Configuration and Nutrient Management in Kharif Maize on Phosphorous Uptake. Int.J.Curr.Microbiol.App.Sci. 8(07): 1380-1388. doi: https://doi.org/10.20546/ijcmas.2019.807.165 